and demonstrations illustrating the work of the Laboratory. Delegates to the conference are being invited from abroad as well as from the British Isles, but considerations of space may limit the total number of visitors. Those who wish to attend should therefore apply to the conference secretary, J. F. Allen, Royal Society Mond Laboratory, Cambridge.

\section{Radiolocation Convention}

A Radiolocation Convention is to be held during March 26-29 at the Institution of Electrical Engineers. At the opening meeting a lecture on the evolution of radiolocation will be given by Sir Robert Watson-Watt. Separate sessions will be devoted to aerials and wave-guides, propagation, cathode ray tubes, valves, radio measurements and test gear, transmitters and receivers, and circuit techniques. Lectures will be given by Mr. W. A. S. Batement on precision radar, by Mr. A. W. Ross on shipborne radar, and by Dr. R. A. Smith on radar in navigation.

\section{Earthquake in Algeria}

Ax approximately 2.46 a.m. on Tuesday, February 12 , an earthquake of considerable intensity affected districts in Northern Algeria, south-west of Constantine. As a result of the shock, considerable damage was done, roads were blocked and communications cut, and it is reported that 276 people were killed and 70 seriously injured. An earthquake occurred in Algeria near Mostaganem on April 1, 1939, and was reported in Nature of July 15, 1939. Previous earthquakes were reported in Nature of June 3, 1933.

\section{New Comet}

A NEW comet was discovered by Timmers at the Vatican Observatory on Feb. 2d. 0h. 10.9m. U.T. Its magnitude was 9 and its tail was less than $1^{\circ}$ in length. Its daily motion was given as R.A. $-1 \mathrm{~m}$. 4ls., Dec. $+1^{\circ} 12^{\prime}$. The comet was observed by Dr. W. H. Steavenson at Cambridge on Feb. 10d. $21 \mathrm{~h}$. $16 \cdot 8 \mathrm{~m}$. Its position then was R.A. $9 \mathrm{~h} .30 \mathrm{~m} .13 \cdot 3 \mathrm{~s}$., Dec. $+52^{\circ} 11 \cdot 5^{\prime}$. Sufficient observations are not yet available to compute an orbit.

\section{T Coronæ Borealis}

THIS star, which appeared as a so-called nova in 1866 and then faded to magnitude 9, was observed by Mr. N. F. H. Knight on Feb. 9 d. 5 h. $30 \mathrm{~m}$. to have a magnitude 3 . It appears to be fading now, as later observations by Mr. W. M. Lindley, Mr. F. M. Holborn and Dr. W. H. Steavenson give its magnitude as about $3 \cdot 5$. It has also been observed at Yerkes; the velocity of expansion has been estimated to be $4,000 \mathrm{~km}$. per second.

\section{The Night Sky in March}

New moon occurs on March 3d. 18h. 01m. U.T. and full moon on March 17d. 19h. 11m. The following conjunctions with the moon take place: March 4d. 20h., Mercury $6^{\circ}$ N.; March 12d. 1lh., Mars $1^{\circ}$ N.; March 12d. 14h., Saturn $2^{\circ}$ S. ; March 20d. 0lh., Jupiter $3^{\circ} \mathrm{S}$. In addition to these conjunctions with the moon, the following conjunctions occur: March 18d. 08h., Mercury in conjunction with Venus, Mercury $5^{\circ}$ N. ; March 19d. 01h., Mars in conjunction with Saturn, Mars $3^{\circ}$ N. No occultations of stars brighter than mag. 6 occur during the month. Mercury is visible in the western sky in the first portion of the month, setting nearly $1 \frac{1}{2}$ hours after the sun. Venus is conspicuous in the western sky, setting at $18 \mathrm{~h} .04 \mathrm{~m} ., 18 \mathrm{~h} .49 \mathrm{~m}$., and $19 \mathrm{~h} .4 \mathrm{~lm}$. at the beginning, middle and end of the month respectively. Mars, in the constellation of Gemini, can be seen during the greater part of the night and does not set at the end of the month before $3 \mathrm{~h} .19 \mathrm{~m}$. Jupiter is well placed for observation, rising at $2 \mathrm{lh}$., $54 \mathrm{~m} ., 20 \mathrm{~h} .54 \mathrm{~m}$., and $19 \mathrm{~h} .40 \mathrm{~m}$. on March 1,15 and 31 respectively. Saturn is easily recognized close to Mars, a conjunction of the planets taking place on March 19. The planet is stationary on March 20. Spring equinox occurs on March 2ld. 06h.

\section{Announcements}

Dr. Julian S. Huxley has been appointed executive secretary of the Preparatory Commission of the United Nations Educational, Scientific and Cultural Organisation.

Sir Harold Spencer Jones, Astronomer Royal, has been elected a member of the Athenæum under the provisions of Rule II of the Club, which empowers the annual election by the committee of a certain number of persons of distinguished eminence in science, literature or the arts, or for their public services.

Prof. A. R. Todd, professor of organic chemistry in the University of Cambridge, will deliver the Pedler Lecture of the Chemical Society on March 7, taking as his subject "Synthesis in the Study of Nucleotides".

THE Quarterly Journal of Microscopical Science was edited by Ray Lankester (with others at first) for fifty-two years, followed by the late Prof. E. S. Goodrich for twenty-six years. They are now succeeded by two joint editors: Dr. C. F. A. Pantin, reader in invertebrate zoology in the University of Cambridge, and Dr. John R. Baker, reader in cytology in the University of Oxford.

DR. J. F. T. Younc, associate professor of physics in the University of Manitoba, has been appointed professor and head of the Department of Physics in the University in succession to emeritus Prof. Frank Allen, founder of the Department (see Nature, 154, $456 ; 1944)$.

Prof. Angeto M. da Costa Lima, a distinguished Brazilian entomologist, has arrived in Britain in the course of a tour of the United States and Europe, sponsored by the Government of Brazil, and is visiting British entomological institutions. He has recently published the sixth volume of a work on "The Insects of Brazil"'.

THe Paul Lewis Laboratories, Inc., of Milwaukee, Wis., have established an annual award of 1,000 dollars and a bronze medal for outstanding research in enzyme chemistry, to be awarded by the American Chemical Society. Candidates for the award must be citizens of the United States less than thirty-six years old and graduates of an American college or university who are non-commercial chemists. The first award will be made in April.

The English Group of the Nutrition Society has arranged a whole-day conference on "Nutrition in the Colonial Territories", to be held on March 2 at the London School of Hygiene and Tropical Medicine. Particulars can be obtained from the honorary secre. tary of the Society, Dr. Leslie J. Harris, Nutritional Laboratory, Milton Road, Cambridge. 